\title{
Nutritional Status of Vitamin $E$ in a Healthy Elderly Population in Japan
}

\author{
Morio Saito, ${ }^{1, *}$ Yoshiki Kobatake, ${ }^{1}$ Masako Tsuchida, ${ }^{2}$ \\ Keiichi Kuroda, ${ }^{3}$ Satoshi Innami, ${ }^{4}$ and Roichi ITOH $^{5}$ \\ ${ }^{1}$ Division of Food Science, The National Institute of Nutrition, Toyama, \\ Shinjuku-ku, Tokyo 162, Japan \\ ${ }^{2}$ Department of Biochemical Research on Food, National Institute of Health, \\ Tokyo 141, Japan \\ ${ }^{3}$ Department of Home Economics, Teikyo Junior College, Tokyo 151, Japan \\ ${ }^{4}$ Department of Nutrition, Tokyo University of Agriculture, Tokyo 156, Japan \\ ${ }^{5}$ Division of Adult Nutrition, The National Institute of Nutrition, Tokyo 162, Japan
}

(Received August 4, 1987)

\begin{abstract}
Summary Serum vitamin E concentration was analysed in 59 (27 males and 32 females) free-living, healthy, middle-income volunteers with mean age of about 68 years (range, 63-73) from the Nagano City area in Japan. We assessed the vitamin E status of this population using two criteria, i.e., serum vitamin $E$ concentration and the ratio of vitamin E (mg) to triglycerides plus cholesterol $(g)$ in serum. Averages $( \pm S D)$ of serum vitamin $\mathrm{E}$ concentration of the population including both males and females were $0.94 \pm 0.26 \mathrm{mg} / \mathrm{dl}$ in July and $0.98 \pm 0.22 \mathrm{mg} / \mathrm{dl}$ in December. In each season, about $15 \%$ of the population had a value of less than $0.7 \mathrm{mg} / \mathrm{dl}$ and were assessed to be under low or marginal vitamin $\mathrm{E}$ status including only one deficient subject $(0.46 \mathrm{mg} / \mathrm{dl})$ in July according to the first criterion. Averages of the ratio of vitamin E to lipid level (triglycerides plus cholesterol) in serum were $3.06 \pm 0.78$ $\mathrm{mg} / \mathrm{g}$ in July and $3.15 \pm 0.76 \mathrm{mg} / \mathrm{g}$ in December. In the latter season, the vitamin $E$ status of one subject was assessed to be in inadequate according to the second criterion. In this population, the values of both lipid peroxides and relative fluorescence intensities in serum, and urinary creatine-to-creatinine ratio were normal in the subjects assessed to have low or marginal vitamin $\mathrm{E}$ by its concentration in serum. These results suggest that the vitamin E status of this population was acceptable, and that the ratio of vitamin $\mathrm{E}$ to lipid level seems to be a more reliable criterion for the assessment of vitamin $\mathrm{E}$ status than its serum concentration.
\end{abstract}

\footnotetext{
*To whom correspondence should be addressed.
} 
Key Words: the elderly, vitamin E status, serum lipids, lipid peroxides, fluorescent substances

Vitamin $\mathrm{E}$ is a natural antioxidant protecting organisms against the harmful effects of free radicals. Although a relationship between free radical reactions and age-related changes is suggested, hardly any investigation has been undertaken to assess the vitamin $\mathrm{E}$ nutriture in free-living elderly Japanese. In addition, no seasonal variation of serum vitamin $\mathrm{E}$ concentration was estimated. For the assessment of vitamin E status, determination of its concentration in serum or plasma is routinely performed in population studies because of its simplicity and convenience. The ratio of the vitamin to lipid levels in serum [1] and concentrations of the vitamin in erythrocytes and/or platelets were also proposed as other criteria by various authors [2-9], although the validity of these criteria is still controversial. Determination of the ratio of urinary creatine to creatinine [10], and of concentrations of lipid peroxides [11-13] and fluorescent substances [14] in serum, as well as the erythrocyte hemolysis test [10,15], are also considered to be useful for assessment of vitamin $\mathrm{E}$ status.

In the present study, we determined the serum vitamin $\mathrm{E}$ concentration in a healthy elderly population in Japan, where seasonal variation of the vitamin was investigated for the same subjects, too. We also assessed the status of the vitamin in this population using the ratio of the vitamin to lipid levels, concentrations of lipid peroxides and fluorescent substances in serum, and the ratio of urinary creatine to creatinine. Furthermore, our purpose is to develop simple and more convenient method to assess the vitamin nutriture for daily screenings.

\section{SUBJECTS AND METHODS}

Fifty-nine male $(n=27)$ and female $(n=32)$ volunteers, 63 years of age or older, were recruited from the Nagano City area for this study. Only subjects without known medical illness were selected. Mean age $( \pm S D)$ was $68.2 \pm 2.6$ (range, 63-73) for males and 67.7 \pm 1.8 (range, 64-72) for females at the start of the study. They were middle-income and lived in their own homes with their relatives. All female subjects were housewives. Male subjects were still active in a variety of occupations; agricultural works, clerical jobs and manual labor were common. Informed consent was obtained from each participant.

The surveys were conducted in July and in December. After an overnight fast, blood was drawn between 09:00 and 11:00 h. Serum vitamin E (tocopherol) was analysed by the method of Abe and Katsui [16] with a slight modification. The serum to which 2,2,5,7,8-pentamethyl-6-hydroxychroman [17] was added as an internal standard, was extracted with $n$-hexane. The extract was injected into a Hitachi gel 3011 column $(2.6 \times 500 \mathrm{~mm})$ and developed with a mixture of methyl alcohol and $n$-hexane $(75: 25)$ on a Hitachi 635 type HPLC equipped with a Hitachi 
650-10S spectrofluorometer. Excitation and emission wavelengths were $298 \mathrm{~nm}$ and $325 \mathrm{~nm}$, respectively.

Total cholesterol and triglycerides in serum were determined by enzymatic methods. Serum lipid peroxides were determined as thiobarbituric acid-reactive substances by the method of Yagi [18] and expressed as nmol malondialdehyde/ml serum. Serum fluorescent substances were measured by the procedure of Tsuchida et al. [14] and expressed in terms of relative fluorescent intensity. Creatine and creatinine in urine were determined by the method of Bonsnes and Taussky [19].

In this study, two criteria were used for the assessment of vitamin E status. One criterion is its concentration in serum. Its level of $0.7 \mathrm{mg} / \mathrm{dl}$ or more was considered to be acceptable, that between 0.5 and $0.7 \mathrm{mg} / \mathrm{dl}$ low or marginal, and that less than $0.5 \mathrm{mg} / \mathrm{dl}$ deficient [20]. This criterion was obtained with adults and children. As it was reported [21] that values of plasma vitamin E concentration derived from a population of healthy adults below 50 years of age were applicable to the healthy elderly, we supposed that the criterion was applicable to a elderly population. The ratio of serum vitamin $\mathrm{E}$ to serum lipid levels was used for another criterion as proposed by Horwitt et al. [1]. In the figures demonstrating the relationship between serum vitamin $\mathrm{E}$ and lipids, they showed that normal and vitamin $\mathrm{E}$ deficient subjects could be separated by a line through the origin which intersected the point representing $0.12 \mathrm{~g}$ triglycerides and $0.45 \mathrm{mg}$ vitamin E per $100 \mathrm{ml}$. With regard to serum cholesterol the dividing line was drawn through the point representing $0.16 \mathrm{~g}$ choresterol and $0.45 \mathrm{mg}$ vitamin E. Accordingly, the dividing line should be drawn through the origin and the point representing $0.28(0.16+0.12) \mathrm{g}$ of triglycerides plus cholesterol and $0.45 \mathrm{mg}$ of vitamin E per $100 \mathrm{ml}$, whose slope is $1.61(0.45 / 0.28)$. For practical purposes and to improve the safety for close inspection, a little higher ratio of $1.65 \mathrm{mg}$ vitamin $\mathrm{E}$ per $\mathrm{g}$ of triglycerides plus cholesterol in $100 \mathrm{ml}$ serum was used as the criterion. When the ratio was 1.65 or more, the nutritional status of this vitamin was assumed to be adequate. When the value was less than 1.65 , it was assumed to be inadequate.

Student's $t$-test was used to determine statistical significance of difference between means.

\section{RESULTS}

\section{Serum vitamin E level}

Table 1 gives the average concentrations of serum $\alpha$ - and $\gamma$-tocopherols of the subjects. About $90 \%$ of the serum tocopherols were $\alpha$-type. In some samples a trace amount of $\delta$-tocopherol was detected. Although the averages of $\alpha$-tocopherol were higher in females than in males, the difference was not statistically significant. Neither was significant seasonal variation observed. Total vitamin E concentrations were significantly higher in females than in males in July (Table 2). Serum vitamin $\mathrm{E}$ concentration correlated positively with concentrations of 
Table 1. Concentrations of serum $\alpha$ - and $\gamma^{\prime}$-tocopherols.

\begin{tabular}{|c|c|c|c|}
\hline & & \multicolumn{2}{|c|}{ Tocopherol concentration $(\mathrm{mg} / \mathrm{dl})$} \\
\hline & & July & December \\
\hline \multirow[t]{2}{*}{ Male } & $\alpha$-Tocopherol & $0.77 \pm 0.20 \quad(n=27)$ & $0.84 \pm 0.20 \quad(n=27)$ \\
\hline & $\gamma$-Tocopherol & $0.08 \pm 0.04 \quad(n=27)$ & $0.08 \pm 0.01 \quad(n=27)$ \\
\hline \multirow[t]{2}{*}{ Female } & $\alpha$-Tocopherol & $0.92 \pm 0.27 \quad(n=31)$ & $0.94 \pm 0.16 \quad(n=32)$ \\
\hline & $\gamma$-Tocopherol & $0.10 \pm 0.05 \quad(n=31)$ & $0.09 \pm 0.05 \quad(n=32)$ \\
\hline \multirow[t]{2}{*}{ Both } & $\alpha$-Tocopherol & $0.85 \pm 0.25 \quad(n=58)$ & $0.90 \pm 0.18 \quad(n=59)$ \\
\hline & $\gamma$-Tocopherol & $0.09 \pm 0.05 \quad(n=58)$ & $0.09 \pm 0.08 \quad(n=59)$ \\
\hline
\end{tabular}

All data are shown as mean \pm SD. Figures in parentheses indicate number of subjects.

Table 2. Serum vitamin E expressed as total concentration or in terms of lipids in serum.

\begin{tabular}{|c|c|c|c|c|}
\hline & \multicolumn{2}{|c|}{ Total vitamin E (mg/dl) } & \multicolumn{2}{|c|}{ Vitamin E/Lipids* } \\
\hline & July & December & July & December \\
\hline Male & $\begin{array}{c}0.84 \pm 0.22 \\
(n=27)\end{array}$ & $\begin{array}{c}0.93 \pm 0.26 \\
(n=27)\end{array}$ & $\begin{array}{c}2.95 \pm 0.86 \\
(n=27)\end{array}$ & $\begin{array}{c}3.13 \pm 1.00 \\
(n=27)\end{array}$ \\
\hline Female & $\begin{array}{c}1.02 \pm 0.27 * * \\
(n=31)\end{array}$ & $\begin{array}{c}1.03 \pm 0.17 \\
(n=32)\end{array}$ & $\begin{array}{c}3.15 \pm 0.86 \\
(n=31)\end{array}$ & $\begin{array}{c}3.18 \pm 0.49 \\
(n=32)\end{array}$ \\
\hline Both & $\begin{array}{c}0.94 \pm 0.26 \\
(n=58)\end{array}$ & $\begin{array}{c}0.98 \pm 0.22 \\
(n=59)\end{array}$ & $\begin{array}{c}\text { 3. } 06 \pm 0.78 \\
(n=58)\end{array}$ & $\begin{array}{c}3.15 \pm 0.76 \\
(n=59)\end{array}$ \\
\hline
\end{tabular}

* Vitamin E (mg)/triglycerides plus cholesterol (g). All data are shown as mean \pm SD. Figures in parentheses indicate number of subjects. ** Mean value is significantly higher than that of males $(p<0.02)$.

serum lipids (triglycerides plus cholesterol: $r=0.5154$ in July and $r=0.4983$ in December, $p<0.01$; triglycerides: $r=0.3519$ in July and $r=0.3741$ in December, $p<0.01$; cholesterol: $r=0.5745$ in July and $r=0.5269$ in December, $p<0.01$; data not shown). Averages of the ratio of total vitamin $\mathrm{E}$ to lipids (triglycerides plus cholesterol) levels in serum are shown in Table 2. No significant difference was observed between the values in males and females. Neither was significant seasonal variation of the values observed.

\section{Assessment of vitamin E status}

Results of the assessment of vitamin E status of the population are summarised in Table 3. Judged from serum vitamin E concentration, one subject was assessed to be in the deficiency category, but only in July, and about $15 \%$ of the population were assessed to have low or marginal status in both seasons. When the vitamin E nutriture was evaluated from the ratio of the vitamin to lipid levels, only one subject was assessed to have an inadequate level, but in December only. 
Table 3. Assessment of vitamin E status of the elderly population.

\begin{tabular}{|c|c|c|c|c|}
\hline & & \multirow{2}{*}{ Category } & \multicolumn{2}{|c|}{ Percentage distribution } \\
\hline & & & $\begin{array}{c}\text { July } \\
(n=58)\end{array}$ & $\begin{array}{c}\text { December } \\
(n=59)\end{array}$ \\
\hline \multirow[t]{3}{*}{ Serum vitamin E (mg/dl) } & $<0.5$ & Deficient & 1.7 & 0 \\
\hline & $0.5-0.7$ & Low & 15.5 & 13.6 \\
\hline & $\geqq 0.7$ & Acceptable & 82.8 & 86.4 \\
\hline \multirow[t]{2}{*}{ Vitamin E/Lipids* } & $<1.65$ & Inadequate & 0 & 1.7 \\
\hline & $\geqq 1.65$ & Adequate & 100.0 & 98.3 \\
\hline
\end{tabular}

* Vitamin E (mg)/triglycerides plus cholesterol (g). Figures in parentheses indicate number of subjects.

Table 4. Lipid peroxides concentrations and relative fluorescence intensities in serum.

\begin{tabular}{lccc}
\hline \multicolumn{1}{c}{ Status } & $\begin{array}{c}\text { Vitamin } \mathrm{E} \\
(\mathrm{mg} / \mathrm{dl})\end{array}$ & $\begin{array}{c}\text { Lipid peroxides } \\
(\mathrm{nmol} / \mathrm{ml})\end{array}$ & $\begin{array}{c}\text { Relative fluorescence } \\
\text { intensity }\end{array}$ \\
\hline Low $(n=7)$ & $0.65 \pm 0.03$ & $5.58 \pm 2.61$ & $21.2 \pm 4.4$ \\
Acceptable $(n=47)$ & $1.03 \pm 0.20^{*}$ & $5.82 \pm 2.13$ & $21.8 \pm 4.9$ \\
\hline
\end{tabular}

All data are shown as mean \pm SD. Figures in parentheses indicate number of subjects.

* Mean value is significantly higher than that of the subjects of low vitamin $\mathrm{E}$ status $(p<0.01)$.

Concentrations of serum lipid peroxides and fluorescent substances, and urinary creatine-to-creatinine ratio

In December, concentrations of lipid peroxides and fluorescent substances were assayed. This was followed by the determination of the urinary creatine-tocreatinine ratio for the same subjects two months later. No significant difference in lipid peroxides levels or relative fluorescence intensities was observed between the subjects judged to be low in vitamin $\mathrm{E}$ from its serum concentration and those whose level was acceptable (Table 4). Neither was any difference observed in the ratio of urinary creatine to creatinine between these two groups (data not shown).

In a subject who was judged to be deficient in vitamin E status in July as measured by serum concentration (Table 3), whose vitamin E concentration was $0.46 \mathrm{mg} / \mathrm{dl}$ and lipid peroxide level $2.30 \mathrm{nmol} / \mathrm{ml}$. Another subject was assessed to be in inadequate status in December as judged by the ratio of the vitamin to lipid levels in serum (Table 3). The ratio of the subject was 1.64, lipid peroxide level $7.31 \mathrm{nmol} / \mathrm{ml}$ and relative fluorescent intensity 20.8. The latter subject was hyperlipemic (total cholesterol, $257 \mathrm{mg} / \mathrm{dl}$; triglycerides, $458 \mathrm{mg} / \mathrm{dl}$ ) and assessed to be in inadequate status although serum vitamin $\mathrm{E}$ concentration was in acceptable range $(1.17 \mathrm{mg} / \mathrm{dl})$. 


\section{DISCUSSION}

For the evaluation of vitamin $\mathrm{E}$ status, the determination of its serum or plasma concentration is routinely used [20-24]. On the other hand, Horwitt et al. [1] proposed that serum lipid levels should be considered in evaluating the nutritional status of the vitamin, because there is a tendency for the serum vitamin $\mathrm{E}$ to rise and fall in proportion to the amount of lipids present in serum. Only in the case where the level of serum or plasma lipids was in the medium range, vitamin $\mathrm{E}$ concentration in serum or plasma was valid to assess the vitamin status [1]. They suggested that a ratio of 0.8 [vitamin E (mg)/total lipids $(\mathrm{g})$ ] or more indicates adequate status of the vitamin. Vandewoude and Vandewoude [25] also made similar proposal to that of Horwitt et al. [1]. As the serum phospholipid or total lipid concentration of the subjects was not determined in the present study, we deduced from the data reported by Horwitt et al. [1] that a ratio of serum vitamine $\mathrm{E}(\mathrm{mg})$ to serum triglycerides plus cholesterol $(\mathrm{g})$ of more than 1.65 indicates adequate status of the vitamin.

Hardly any investigation has been undertaken to assess the vitamin E nutriture in free-living elderly Japanese. When the nutritional status of the vitamin of the population was assessed by its concentration in serum as proposed by Sauberlich et al. [20], about $15 \%$ of the population were considered to have low or marginal status. However, when the vitamin status was assessed in terms of the ratio of vitamin $\mathrm{E}$ to lipid levels in serum, status of this vitamin in almost all the subjects was estimated to be adequate. Similar results were obtained in adults by Desai et al. [23, 24], in pregnant women by Haga et al. [26], in sickle cell anemia subjects by Natta and Machlin [27], and in children by Farrell et al. [28]. From these results more than about $85 \%$ of this elderly population were in satisfactory status of vitamin $\mathrm{E}$ even when assessed by its vitamin concentration in serum. Furthermore, no seasonal variation of serum vitamin E concentration was observed.

It has been shown that vitamin $\mathrm{E}$ deficiency induces lipid peroxidation in vivo [29-31], an increase in fluorescent substances in serum and tissues [14, 3234 , and a rise in the ratio of urinary creatine to creatinine [10] via decreased antioxidative action of the vitamin. In this population, the serum values of both lipid peroxides and relative fluorescence intensities were normal even in the subjects assessed to be in low or marginal vitamin $\mathrm{E}$ status by its concentration in serum. A similar result was also obtained between the ratio of urinary creatine to creatinine and vitamin $E$ status. In the case of the subject assessed to be in deficient vitamin E status $(0.46 \mathrm{mg} / \mathrm{dl})$ in July, serum lipid peroxide level $(2.30 \mathrm{nmol} / \mathrm{ml})$ was normal according to Yagi and Nishigaki [35]. In another subject judged to be in inadequate status of the vitamin $(1.64 \mathrm{mg}$ vitamin $\mathrm{E}$ per $\mathrm{g}$ of triglycerides plus cholesterol in $100 \mathrm{ml}$ serum) in December, serum lipid peroxide level (7.31 $\mathrm{nmol} / \mathrm{ml}$ ) was high [35] though the relative fluorescence intensity was normal 
(20.8). From these results, we conclude that the vitamin E status of this population is adequate and that serum or plasma lipid levels should be considered in the assessment of vitamin $\mathrm{E}$ status, supporting the proposal of Horwitt et al. [1]. But erythrocyte hemolysis test $[16,17]$ or determination of vitamin $E$ in erythrocytes [2-6] and/or platelets [7-9] is necessary for more accurate assessment for the subject who were judged to be in inadequate status of vitamin $\mathrm{E}$.

This study was supported by grants from Science and Technology Agency and Nagano City. Cooperation of the staff of the Nagano Dietetic Association is gratefully acknowledged.

\section{REFERENCES}

1. Horwitt, M.K., Harvey, C.C., Dahm, C.H., Jr., and Searcy, M.T. (1972): Relationship between tocopherol and serum lipid levels for determination of nutritional adequacy. Ann. NY. Acad. Sci., 203, 223-236.

2. Mino, M., Nakagawa, S., Tamai, H., and Miki, M. (1982): Clinical evaluation of red blood cell tocopherol. Ann. NY. Acad. Sci., 393, 175-178.

3. Mino, M., Kitagawa, M., and Nakagawa, S. (1985): Red blood cell tocopherol concentrations in a normal population of Japanese children and premature infants in relation to the assessment of vitamin E status. Am. J. Clin. Nutr., 41, 631-638.

4. Mino, M., and Nagamatsu, M. (1986): An evaluation of nutritional status of vitamin $\mathrm{E}$ in pregnant women with respect to red blood cell tocopherol level. Int. J. Vitam. Nutr. Res., 56, 149-153.

5. Mino, M., Kasugai, O., and Shimizu, T. (1985): Red blood cell tocopherol and liver tocopherol in hyperlipemic rats as compared with plasma tocopherol. Lipids, 20, 488-491.

6. Mino, M., Kitagawa, M., and Nakagawa, S. (1981): Changes of alpha-tocopherol levels in red blood cells and plasma with respect to hemolysis induced by dialuric acid in vitamin E-deficient rats. J. Nutr. Sci. Vitaminol., 27, 199-207.

7. Lehmann, J. (1981): Comparative sensitivities of tocopherol levels of platelets, red blood cells, and plasma for estimating vitamin E nutritional status in the rat. Am. J. Clin. Nutr., 34, 2104-2110.

8. Vatassery, G.T., Morley, J.E., and Kuskowski, M.A. (1983): Vitamin E in plasma and platelets of human diabetic patients and control subjects. Am. J. Clin. Nutr., 37, 641-644.

9. Vatassery, G.T., Krezowski, A.M., and Eckfeldt, J.H. (1983): Vitamin E concentrations in human blood plasma and platelets. Am. J. Clin. Nutr., 37, 1020-1024.

10. Horwitt, M.K. (1960): Vitamin $\mathrm{E}$ and lipid metabolism in man. Am. J. Clin. Nutr., 8, 451461.

11. Kibata, M., Shimizu, Y., Miyake, K., Shoji, K., Miyahara, K., Nasu, Y., and Kimura, I. (1978): Studies on vitamin E in lipid metabolism, in Tocopherol, Oxygen and Biomembranes, ed. by De Duve, C., and Hayaishi, O., Elsevier/North-Holland Biomedical Press, Amsterdam, pp. 283-295.

12. Kobatake, Y., Kuroda, K., Jinnouchi, H., Nishide, E., and Innami, S. (1984): Differential effects of dietary eicosapentaenoic and docosahexaenoic fatty acids on lowering of triglyceride and cholesterol levels in the serum of rats on hypercholesterolemic diet. J. Nutr. Sci. Vitaminol., 30, 357-372.

13. Kobatake, Y., Saito, M., Kuroda, K., Kobayashi, S., and Innami, S. (1987): Influence of fish consumption on serum lipid and lipid peroxide concentrations in middle aged subjects. J. Jpn. Soc. Nutr. Food Sci., 40, 103-110.

Vol. 4, No. 2, 1988 
14. Tsuchida, M., Miura, T., Mizutani, K., and Aibara, K. (1985): Fluorescent substances in mouse and human sera as a parameter of in vivo lipid peroxidation. Biochim. Biophys. Acta, 834, 196-204.

15. Horwitt, M.K., Harvey, C.C., Duncan, G.D., and Wilson, W.C. (1956): Effects of limited tocopherol intake in man with relationships to erythrocyte hemolysis and lipid oxidations. Am. J. Clin. Nutr., 4, 408-419.

16. Abe, K., and Katsui, G. (1975): Determination of tocopherols in serum by high speed liquid chromatography. Vitamins (Japan), 49, 259-263.

17. Smith, L.I., Ungnade, H.E., Hoehn, H.H., and Wawzonek, S. (1939): The chemistry of vitamin E. VI. The addition of dienes to phenols and hydroquinones. J. Org. Chem., 4, 311-317.

18. Yagi, K. (1976): A simple fluorometric assay for lipoperoxide in blood plasma. Biochem. Med., 15, 212-216.

19. Bonsnes, W., and Taussky, H.H. (1945): On the colorimetric determination of creatinine by the Jaffe reaction. J. Biol. Chem., 158, 581-591.

20. Sauberlich, H.E., Dowdy, R.P., and Skala, J.H. (1973): Laboratory tests for the assessment of nutritional status. Vitamin E (Tocopherol). CRC Crit. Rev. Clin. Lab. Sci., 4, 288-294.

21. Schriver, J., van Veelen, B.W.C., and Schreurs, W.H.P. (1985): Biochemical evaluation of the vitamin and iron status of an apparently healthy Duch free-living elderly population. Comparison with younger adults. Int. J. Vitam. Nutr. Res., 55, 337-349.

22. Combs, G.F. (1981): Assessment of vitamin E status in animals and man. Proc. Nutr. Soc., 40, 187-194.

23. Desai, I.D., Tavares, M.L.G., de Oliveira, B.S.D., Douglas, A., Duarte, F.A.M., and de Oliviera, J.E.D. (1980): Food habits and nutritional status of agricultural migrant workers in Southern Brazil. Am. J. Clin. Nutr., 33, 702-714.

24. Desai, I.D., Swann, M.A., Tavares, M.L.G., de Oliveira, B.S.D., Pharm, B., Cuarte, F.A.M., and de Oliveira, J.E.D. (1980): Vitamin E status of agricultural migrant workers in Southern Brazil. Am. J. Clin. Nutr., 33, 2669-2673.

25. Vandewoude, M.F.J., and Vandewoude, M.G. (1987): Vitamin E status in a normal population: the influence of age. J. Am. Coll. Nutr., 6, 307-311.

26. Haga, P., Ek, J., and Kran, S. (1982): Plasma tocopherol levels and vitamin E/ $\beta$-lipoprotein relationships during pregnancy and in cord blood. Am. J. Clin. Nutr., 36, 1200-1204.

27. Natta, C., and Machlin, L. (1979): Plasma levels of tocopherol in sickle cell anemia subjects. Am. J. Clin. Nutr., 32, 1359-1362.

28. Farrel, P.M., Levine, S.L., Murphy, M.D., and Adams, A.J. (1978): Plasma tocopherol levels and tocopherol-lipid relationships in a normal population of children as compared to healthy adults. Am. J. Clin. Nutr., 31, 1720-1726.

29. Tappel, A.L. (1962): Vitamin E as the biological lipid antioxidant. Vitam. Horm., 20, 493-510.

30. Derrick, N.M., and Wishner, L.A. (1967): Autoxidation of tissue lipids. I. Incorporation of dietary fatty acids and formation of monocarbonyl compounds in adipose tissue lipids of the vitamin E-deficient rat. Lipids, 2, 133-136.

31. Chow, C.K., and Tappel, A.L. (1972): An enzymatic protective mechanism against lipid peroxidation damage to lungs of ozone-exposed rats. Lipids, 7, 518-524.

32. Dillard, C.J., and Tappel, A.L. (1971): Fluorescent products of lipid peroxidation of mitochondria and microsomes. Lipids, 6, 715-721.

33. Csallany, A.S., and Ayaz, K.L. (1976): Quantitative determination of organic solvent soluble lipofuscin pigments in tissues. Lipids, 11, 412-417.

34. Blackett, A.D., and Hall, D.A. (1981): Tissue vitamin E levels and lipofuscin accumulation with age in the mouse. J. Gerontol., 36, 529-533.

35. Yagi, K., and Nishigaki, I. (1982): Normal values of serum lipids. Sohgoh Rinshou, 31, 2758-2762 (in Japanese). 